\title{
Comparative evaluation of baseline cleanliness of food contact surfaces in fishery based microenterprise units by ATP-Bioluminescence and conventional microbiological methods
}

\author{
F. HASSAN, K. V. NIJA AND T. V. SANKAR \\ ICAR-Central Institute of Fisheries Technology, Matsyapuri, P.O., Kochi - 682 029, Kerala, India \\ e-mail:femeenahassan@rediffmail.com
}

\begin{abstract}
The baseline cleanliness of food contact surfaces namely floor, working tables, workers' hands, utensils and machinery of a fishery-based microenterprise were examined by traditional microbiological swab analysis method and ATP-bioluminescence method. The study showed that swab results, measured in relative light unit which is proportional to total recovered ATP, did not have significant correlation with standard method of microbiological swab in the adjacent sites of equal area. The study also examined the bactericidal efficiency of selected commercially available sanitisers and the effect of treatment was found to be significantly different from each other. Analysis of percentage reduction of bacterial load on food contact surfaces showed that commercially available stabilised hydrogen peroxide was more effective than sodium hypochlorite used in the food industries $(\mathrm{p}<0.05)$.
\end{abstract}

Keywords: ATP-bioluminescence, Food contact surfaces, Luminometry, Microbiology, Sanitiser

Food quality and safety are the major concerns facing the food industry today. Numerous cases of food spoilage and contamination with bacteria have been traced back to failure or insufficiency in safety procedures. The increasing incidence of food-borne diseases emphasises the importance of improving and maintaining high standard of food safety in food service establishments and there is substantial evidence to show that fish and fish products are high on the list of food products that cause food-borne diseases (Huss, 1995).

There are reports suggesting that food handled in small and medium-sized establishments are of lower microbiological quality than those in the larger establishments (Norrung and Buncic, 2008; Violaris et al., 2008). Food Safety Management System (FSMS) is a system of managing internal practices to ensure safety of food being produced and may include systems from Good Manufacturing Practices (GMPs) to Hazard Analysis and Critical Control Point (HACCP). Small and medium sized food businesses like micro-enterprise units have been slow to adopt FSMS and the lack of hygiene is related to poor education, financial constraints and lack of awareness in food safety (Violaris et al., 2008). The major routes of contamination in seafood processing plants are food contact surfaces (Vogel et al., 2001). The Canadian Food Inspection Agency defined food contact surface as any equipment or utensil which normally comes in contact with the food product or surfaces normally in contact with the product (Holah et al., 1998). It is essential to control microorganisms on processing equipment to provide consumers with safe and wholesome product (Lelieveld, 1985; Pontefract, 1991).

The use of sanitisers and the cleaning schedule has an important role in ensuring the safety of food contact surfaces. A powerful tool for the detection of risks associated with the production, manufacture and consumption of seafood is hygiene monitoring of food contact surfaces. The main causes of microbial contamination typically occurring in food service establishments are contaminated supplies, dirty food contact surfaces, poor personnel hygiene practices, inappropriate storage temperatures, lack of proper facilities and insufficient cooking (Kaferstein, 2003; EFSA, 2007; Jones et al., 2008). Attachment of bacteria to food contact surfaces can lead to product contamination, spoilage and surface deterioration (Wirtanen et al., 2000).

Though conventional microbiological methods are popular and used by many laboratories for rapid detection of microorganisms, ATP-bioluminescence based on adenosine triphosphate (ATP) found in all living organisms, is an excellent marker for checking the viability and cellular contamination. This system delivers a rapid, direct, objective measurement of cleaning efficiency, hygienic status and risk, primarily by the measurement of ATP. Rapid microbial detection is increasingly essential in food processing establishments that would allow cost saving and would speed up product release.

Disinfection usually involves use of chemicals, heat or ultraviolet light. Commercially available stabilised 
hydrogen peroxide and sodium hypochlorite can be used to disinfect food contact surfaces. Stabilised hydrogen peroxide is effective against a broad range of pathogenic bacteria including enveloped and non-enveloped viruses, vegetative bacteria, fungi and bacterial spores. Hypochlorites are the most widely used chlorine sanitisers and are available in liquid (e.g. sodium hypochlorite) or solid (e.g. calcium hypochlorite, sodium dichloroisocyanurate) form. Disinfection, however, does not destroy bacterial spores. The present study was undertaken to assess the baseline cleanliness of food contact surfaces in selected sea food microenterprise units using traditional microbiological swab analysis and ATP-bioluminescence method. The study also evaluated the efficiency of sanitisers namely sodium hypochlorite and stabilised hydrogen peroxide in removing biological hazards from contact surfaces.

For the study, three fishery based women microenterprises in Cochin (shrimp peeling units) were identified. From the microenterprise units, 5 different food contact surfaces viz., working table, floor, workers' hand, utensil and machinery were selected. Bacterial load of these 5 food contact surfaces was estimated before and after treatment with sodium hypochlorite and stabilised hydrogen peroxide at different intervals. The concentration of sanitisers applied in different food contact surfaces and the contact time were as per Hassan et al. (2013). The concentration of sodium hypochlorite used on working table, floor, workers' hand, utensil and machinery were 100, 200, 20, 50 and 50 ppm, respectively. The concentration of stabilised hydrogen peroxide used for sanitising workers' hand was $200 \mathrm{ppm}$ and for all other food contact surfaces the concentration used was $1000 \mathrm{ppm}$. For sanitising workers hand, on one hand sodium hypochlorite and on the other hand stabilised hydrogen peroxide were used. The contact time given was $20 \mathrm{~min}$ for both the sanitisers. This was considered as $0 \mathrm{~h}$. In order to see the duration of effect, the swab samples were also taken after 2 and $4 \mathrm{~h}$. Swab analysis was done using the traditional method of microbiological analysis as well as using ATPbioluminescence method. From each microenterprise unit, three samples were taken and the TPC values given in Table 1 are the mean of all the values $(3 \times 3)$.

Cleanliness status by bioluminescence was assessed in the present study using ATP hygiene monitoring system (Hygiena Systemsure Plus). The measurement procedure was performed following the instructions of the manufacturers of the meter and swabs. The time and date of the instrument was set to ensure its normal operation and accuracy. Total testing time including the reading did not exceed $45 \mathrm{sec}$. The results are given in relative light units (RLU). ATP-B samples were collected with clean surface swabs according to manufacturer's instructions (Hygiena Systemsure Plus). The selected surfaces were swabbed in a zigzag pattern, while rotating swabs and applying slight pressure. Sample was transferred aseptically to the ultra-snap tube. The device was activated by holding the test tube firmly and breaking the snap valve by bending the bulb forward and backward. The bulb was squeezed to expel the liquid completely down the shaft. The sample collection tip was soaked in liquid by gently shaking for 5-10 sec. The ultra-snap tube with sample was then inserted into the luminometer, the lid was closed and the reading was taken using the instrument. The ultra-snap tube containing an ATP bioenzyme, D-luciferin, was then added to the sampler to react with the swab taken and convert ATP into AMP (Adenosine monophosphate). The higher the RLU results, higher the contamination level in the sample. The relationship between ATP and RLU could be identified as $1 \mathrm{RLU}=1 \times 10^{-15} \mathrm{~mol}$ ATP.

Samples for aerobic plate count (APC) analysis were collected using sterile swabs from the adjacent area from where swab samples were collected for ATP-B sampling. A sterile swab, moistened with phosphate buffer was rubbed for $20 \mathrm{sec}$ over the surface to be sampled. Sampling of the entire selected surface was done using a sterile template of $25 \mathrm{~cm}^{2}$ that was used to outline a known area, inside which the swabbing was done. The swab was then placed in $100 \mathrm{ml}$ buffer and stored in an ice container and then analysed within $1 \mathrm{~h}$ of arrival at the laboratory. One $\mathrm{ml}$ aliquots were pourplated on melted plate count agar $(15-20 \mathrm{ml})$. After solidifying the agar, petri dishes were inverted and incubated at $35^{\circ} \mathrm{C}$ for $48 \pm 2 \mathrm{~h}$. Colony forming units (CFU) were counted after the incubation period.

The results were analysed using the analysis of variance (ANOVA) technique and means were separated using the Tukey ' $\mathrm{B}$ ' test at 5\% level of significance using SPSS16.0.

The total plate count values obtained by traditional microbiological swabbing are given in Table 1 . The results clearly indicate the reduction in bacterial load from the initial values after the application of sanitisers. It is evident from Tables 1 and 2 that reduction of total bacteria was higher in the area where stabilised hydrogen peroxide was used as sanitiser. In all cases, use of stabilised hydrogen peroxide showed longer retention than sodium hypochlorite. After $20 \mathrm{~min}$ of application of sanitisers, bacterial load was found to be significantly $(p<0.05)$ reduced from initial values in both the cases. It was also clear that floor samples contained higher bacterial load (floor $>$ workers hand $>$ working table $>$ machinery $>$ utensil) and least bacterial load was found on the utensils. Sodium hypochlorite is used widely as sanitiser in food industries. As a strong oxidising agent, hypochlorite is known to be very active in killing most bacteria, fungi and viruses. Our results show that its activity was very low after $2 \mathrm{~h}$ of application while the sanitising property of stabilised hydrogen peroxide still persisted (Fig. 1 and 2). The advantage of stabilised hydrogen peroxide is long term 
Table 1. Total plate count from different surfaces after the application of sanitisers

\begin{tabular}{|c|c|c|c|c|c|c|c|}
\hline \multirow{3}{*}{ Surfaces } & \multicolumn{7}{|c|}{ Total plate count $\left(\mathrm{cfu} \mathrm{cm}^{-2}\right)$} \\
\hline & \multirow{2}{*}{ Initial value (control) } & \multicolumn{2}{|c|}{ After $20 \mathrm{~min}$} & \multicolumn{2}{|c|}{ After $2 \mathrm{~h}$} & \multicolumn{2}{|c|}{ After $4 \mathrm{~h}$} \\
\hline & & $\mathrm{T} 1$ & $\mathrm{~T} 2$ & $\mathrm{~T} 1$ & $\mathrm{~T} 2$ & $\mathrm{~T} 1$ & $\mathrm{~T} 2$ \\
\hline Working table & $6.33 \times 10^{2}$ & $80^{\mathrm{a}}$ & $93^{\mathrm{b}}$ & $1.88 \times 10^{2 \mathrm{a}}$ & $1.64 \times 10^{2 b}$ & $2.56 \times 10^{2 \mathrm{a}}$ & $1.96 \times 10^{2 \mathrm{~b}}$ \\
\hline Floor & $3.054 \times 10^{3}$ & $2.60 \times 10^{2 a}$ & $2.71 \times 10^{2 b}$ & $8.24 \times 10^{2 \mathrm{a}}$ & $6.78 \times 10^{2 \mathrm{~b}}$ & $1.157 \times 10^{3 \mathrm{a}}$ & $7.72 \times 10^{2 b}$ \\
\hline Worker's hand & $7.96 \times 10^{2}$ & $51^{\mathrm{a}}$ & $78^{\mathrm{b}}$ & $2.15 \times 10^{2 a}$ & $1.17 \times 10^{2 b}$ & $2.86 \times 10^{2 \mathrm{a}}$ & $1.60 \times 10^{2 b}$ \\
\hline Utensil & $2.62 \times 10^{2}$ & $19^{\mathrm{a}}$ & $28^{\mathrm{b}}$ & $61^{\mathrm{a}}$ & $49^{\mathrm{b}}$ & $1.17 \times 10^{2 a}$ & $83^{\mathrm{b}}$ \\
\hline Machinery & $5.88 \times 10^{2}$ & $51^{\mathrm{a}}$ & $52^{\mathrm{a}}$ & $1.90 \times 10^{2 \mathrm{a}}$ & $1.29 \times 10^{2 b}$ & $2.68 \times 10^{2 a}$ & $1.86^{\mathrm{b}}$ \\
\hline
\end{tabular}

T1-Sodium hypochlorite; T2-Stabilised hydrogen peroxide

Values bearing different superscripts differ significantly $(\mathrm{p}<0.05)$

Table 2. Relative light unit (RLU) from different surfaces after the application of sanitisers (mean \pm SD)

\begin{tabular}{|c|c|c|c|c|c|c|c|}
\hline \multirow{3}{*}{ Surfaces } & \multicolumn{7}{|c|}{$\mathrm{cfu} \mathrm{cm}^{-2}$} \\
\hline & \multirow{2}{*}{$\begin{array}{l}\text { Initial value } \\
\text { (control) }\end{array}$} & \multicolumn{2}{|l|}{ After $20 \mathrm{~min}$} & \multicolumn{2}{|l|}{ After $2 \mathrm{~h}$} & \multicolumn{2}{|l|}{ After $4 \mathrm{~h}$} \\
\hline & & $\mathrm{T} 1$ & $\mathrm{~T} 2$ & $\mathrm{~T} 1$ & $\mathrm{~T} 2$ & $\mathrm{~T} 1$ & $\mathrm{~T} 2$ \\
\hline Working table & $790 \pm 33.045$ & $87.33 \pm 3.055^{\mathrm{a}}$ & $89 \pm 1^{\mathrm{a}}$ & $224.667 \pm 16.74^{\mathrm{a}}$ & $156.33 \pm 11.71^{\mathrm{b}}$ & $310.33 \pm 13.65^{\mathrm{a}}$ & $241.667 \pm 17.5$ \\
\hline Floor & $4216.33 \pm 103.01$ & $383 \pm 26.51^{\mathrm{a}}$ & $417.667 \pm 26.95^{\mathrm{b}}$ & $930 \pm 95.39^{\mathrm{a}}$ & $916.33 \pm 172.65^{b}$ & $1554 \pm 193.62^{\mathrm{a}}$ & $998 \pm 72.13^{b}$ \\
\hline Worker's hand & $1210.667 \pm 14.74$ & $58.33 \pm 6.42^{\mathrm{a}}$ & $71 \pm 7.211^{\mathrm{b}}$ & $286 \pm 87.98^{\mathrm{a}}$ & $204 \pm 8.48^{b}$ & $384.667 \pm 50.619^{\mathrm{a}}$ & $285.667 \pm 87.4^{b}$ \\
\hline Utensil & $555.33 \pm 22.14$ & $37 \pm 6.244^{\mathrm{a}}$ & $37.33 \pm 2.51^{\mathrm{a}}$ & $134 \pm 14.42^{\mathrm{a}}$ & $91.33 \pm 17.38^{\mathrm{b}}$ & $222.33 \pm 17.38^{\mathrm{a}}$ & $184 \pm 30.51^{\mathrm{b}}$ \\
\hline Machinery & $848 \pm 19.69$ & $66.67 \pm 4.041^{\mathrm{a}}$ & $74 \pm 6.244^{b}$ & $259.33 \pm 62.06^{\mathrm{a}}$ & $154.667 \pm 47.05^{\mathrm{b}}$ & $358.33 \pm 14.5^{\mathrm{a}}$ & $275.33 \pm 37.89^{b}$ \\
\hline
\end{tabular}

T1-Sodium hypochlorite; T2-Stabilised hydrogen peroxide

Values bearing different superscripts differ significantly $(\mathrm{p}<0.05)$

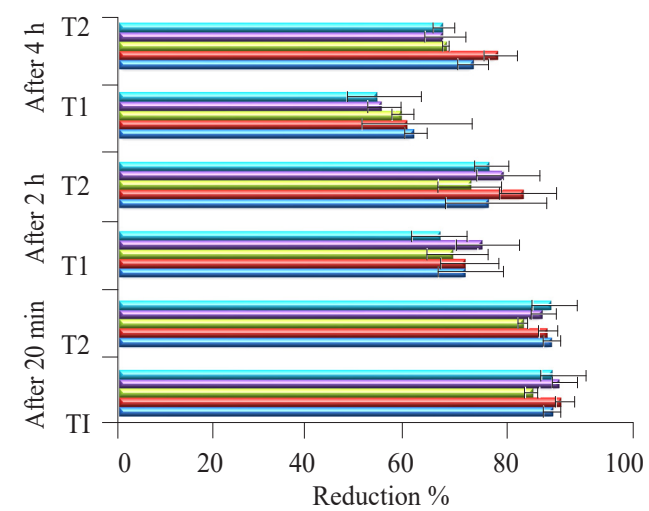

T1-Sodium hypochlorite; T2-Stabilised hydrogen peroxide

$\square$ Machinery, $\square$ Utensil, $\square$ Working table, $\mathbf{\square}$ Worker's hand, $\mathbf{\square}$ Floor

Fig. 1. \% reduction of total plate count from different surfaces after the application of sanitiers for different time periods

effectiveness even in low concentrations. A study by Hassan et al. (2013) showed that stabilised hydrogen peroxide fulfills all the requirements for sanitisers like free of odour, colour and taste and ability to eliminate becteria, virus, mold, fungi, amoeba, spores and biofilms.

The main difference between stabilised hydrogen peroxide and ordinary hydrogen peroxide lies in the presence of the nano quantity of silver nitrate and organic acid which serve as a 'stabiliser and activator' at the same time. This

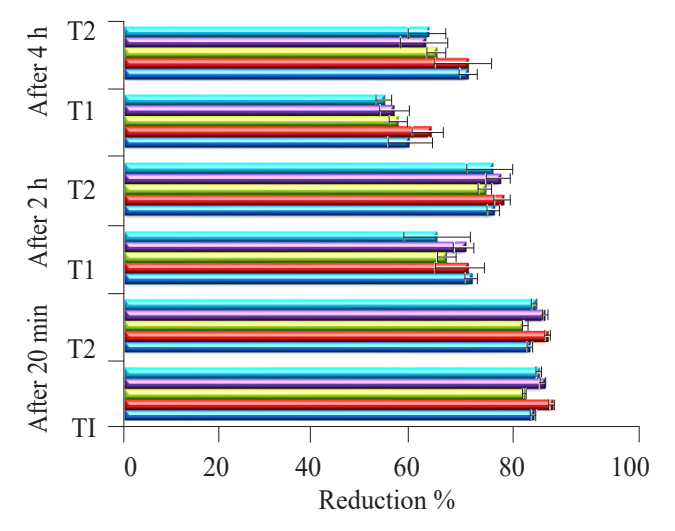

T1-Sodium hypochlorite; T2-Stabilised hydrogen peroxide $\square$ Machinery, $\square$ Utensil, $\square$ Working table, $\square$ Worker's hand, $\square$ Floor

Fig. 2. \% reduction of relative light unit (RLU) from different surfaces after the application of sanitisers for different time periods

stabiliser prevents decomposition of hydrogen peroxide. Nano-quantity of silver nitrate also serves as a disinfectant to boost up the effect of $\mathrm{H}_{2} \mathrm{O}_{2}$. In contact with bacterial cell and other biological material, silver reacts and loses its stabilising function which leads to the activation of the hydrogen peroxide. The capacity of silver to activate hydrogen peroxide is preserved until silver nitrate is fully used by the biological material. As long as some silver nitrate is left over, some amount of $\mathrm{H}_{2} \mathrm{O}_{2}$ will remain stable and will be available 
for long time disinfection effect. Hence stabilised $\mathrm{H}_{2} \mathrm{O}_{2}$ is a better disinfectant for achieving sanitation and hygiene in food processing industry, particularly in the protein and moisture rich fish processing industry. It is ecofriendly and least harmful compared to chlorine and its derivatives

ATP-bioluminescence and traditional microbiological swab culture methods were used for detection of surface hygiene of the selected food contact surfaces of the micro enterprise unit. No significant difference was observed between the two methods of assessing the cleanliness of the food contact surfaces. ATP-B testing can be considered as an efficient tool to facilitate creation, implementation and validation of more effective food contact surface cleaning in food establishments (Cunningham et al., 2011). The ATP-bioluminescence method detects higher levels of contamination than traditional swabbing method. Clean surfaces generally show relatively low levels of total ATP. Therefore, a light output more than two-fold compared to that of the clean surface indicates that the tested area is contaminated with biological material. The oldest and most widely used method for monitoring hygiene is swabbing either with sterile swabs or sponges, rinsing and cultivating the collected bacteria (Miettinen et al., 2001). This remains the most common approach used routinely by laboratories for the routine determination of total viable counts, also referred to as aerobic plate count. This test involves using a pour plate technique, plating appropriate dilutions of the sample and incubating the plates at $30^{\circ} \mathrm{C}$ for $48 \mathrm{~h}$ (ISO: 4833, 2003). Traditional swabbing methods give the actual bacterial counts, but a study by Griffith et al. (2001) revealed that the traditional swabbing methods can cause cellular damage to bacteria. Moreover, the way swab is taken, transported and its effective dilution in the solvent can also influence the enumeration of bacteria in traditional method of swabbing.

Improvement of the microenterprise unit's hygiene was clearly identifiable after treatment with the sanitisers. The overall microbiological counts decreased after treatment with sodium hypochlorite and stabilised hydrogen peroxide. Considerable reduction of the overall microbiological counts occurred after treatment with stabilised hydrogen peroxide rather than sodium hypochlorite. The results showed that there is considerable difference after the treatment with both the sanitisers. The effectiveness of the two treatments in reducing bacterial load was confirmed by comparing the data on bacterial load (traditional microbiological swab analysis) and cleanliness (ATP-bioluminescence) before and after treatment from 5 food contact surfaces in the microenterprise unit $(\mathrm{p}<0.05)$. The study is in agreement with Hassan e. al. (2013) and points out the effectiveness of total bacterial count reduction which was higher when hydrogen peroxide (up to 4 h) was used.
Fig. 1 and 2 clearly show that there was considerable reduction in the bacterial count on different surfaces after 20 min contact time with the sanitisers. The retention time was found to be higher for stabilised hydrogen peroxide than sodium hypochlorite, as the percentage reduction was more in the case of stabilised hydrogen peroxide. Table 2 summarises the relative light unit of microbial load of two different sanitisers at three different timings viz., $0 \mathrm{~h}$ (after 20 min contact time), 2 and $4 \mathrm{~h}$. As the time of application increased, the rate of retention of sanitizer was found to be lower for sodium hypochlorite than stabilised hydrogen peroxide. Higher values of ATP were detected on the floor and on workers' hands.

Among the selected surfaces, bacterial load was higher in floor and machinery and lower in worker's hand when compared to other selected food contact surfaces. Although the bacterial load was found to be less in workers' hand, this plays a major role in maintenance of hygiene (Walker et al., 2003). It is evident from the Table that the initial microbial loads in the bare hands of the workers were higher and considerable reduction was seen when cleaned with chlorine and hydrogen peroxide. After treatment with both sanitisers, traditional microbiological swab analysis as well as the hygiene monitoring system showed lower microbial load.

Though microbial standard of food contact surface is available for seafood export processing units, no standards are available for microenterprise units handling seafoods. Further, the results indicate that even though the unit is a detached preprocessing area, there is a clear need to improve cleaning and hygiene practices in the microenterprise units and train the food handlers on the importance and practice of hygiene.

\section{Acknowledgements}

The authors are grateful to the Department of Science and Technology, New Delhi for the financial support to carry out the study. The authors are also thankful to the Director, ICAR-CIFT, Kochi for providing facilities to carry out this work.

\section{References}

Cunningham, A. E., Rajagopal, R. and Lauer, J. 2011. Assessment of hygienic quality of surfaces in retail food service establishments based on microbial counts and real-time detection of ATP. J. Food Prot., 74(4): 686-690.

EFSA.2007. Opinion of the scientific panel on biological hazards on microbiological criteria and targets based on risk analysis. European Food Safety Authority, EFSA J., 462: 1-29.

Griffith, C. J., Price, P., Peters, A. and Clayton, D. 2001. An evaluation of food handlers knowledge, belief and attitudes about food safety and its interpretation using social cognition models. Food Standards Agency, London. 
Hassan, F., Lakshmanan, P. T., Geethalakshmi, V. and Mukundan, M. K. 2013. Evaluation of stabilised hydrogen peroxideas sanitiser in seafood processing. Indian J. Fish., 60(2): 145-149.

Holah, J. T., Lavaud, A., Peters, W. and Dye, K. A. 1998. Future techniques for disinfectant efficacy testing. Int. Biodeterior. Biodegradation, 41: 273-279.

Huss, H. H. 1995. Quality and quality changes in fresh fish. FAO Fisheries Technical Paper no. 348, Food and Agricultural Organisation, Rome, Italy.

ISO 2003. Microbiology of food and animal feeding stuffs Horizontal method for the enumeration of microorganisms with Colony-count technique at $30^{\circ} \mathrm{C}$. https://www.iso.org/ standard/ 34524.html (Accessed 10 November 2015).

Jones, S. L., Parry, S. M., O’brein, S. J. and Palmer, S. R. 2008. Are staff management practices and inspection risk ratings associated with foodborne disease outbreaks in the catering industry in England and Wales? J. Food Prot., 71: 550-557.

Kaferstein, F. K. 2003. Food safety: The fourth pillar in the strategy to prevent infant diarrhoea. Bull. World Health Organ., 81(11): 842-843.

Lelieveld, H. L. M. 1985. Hygienic design and test methods. J. Soc. Dairy Technol., 38: 14-16.
Miettinen, H., Aarnisalo, K., Salo, A. and Sjoberg, M. 2001. Evaluation of surface contamination and the presence of Listeria monocytogenes in fish processing factories. J. Food Prot., 64(5): 635-639.

Norrung, B. and Buncic, S. 2008. Microbial safety of meat in the European Union. Meat Sci., 78: 14-24.

Pontefract, R. D. 1991. Bacterial adherence: its consequences in food processing. Can. Inst. Sci. Technol. J., 24: 113-117.

Violaris, Y., Bridges, O. and Bridges, J. 2008. Small businesses big risks: Current status and future direction of HACCP in Cyprus. Food Control, 19: 439-448.

Vogel, F. B., Huss, H. H., Ojeniyi, B., Ahrens, P. and Lone, G. 2001. Elucidation of Listeria monocytogenes contamination routes in cold smoked salmon processing plants detected by DNA-based typing methods. Appl. Environ. Microbiol., 67(6): 2586-2595.

Walker, E., Pritchard, C. and Forsythe, S. 2003. Food handlers' hygiene knowledge in small food business. Food Control, 14: 339-343.

Wirtanen, G., Saarela, M. and Mattila-Sandholm, T. 2000. BiofilmsImpact on hygiene in food industries. In: Bryers, J. D. (Ed.), Biofilms II: Process analysis and applications. Wiley-Liss, New York, 432 pp. 